\title{
Reclaiming the Chinese Revolution
}

\section{Citation}

Perry, Elizabeth J. 2008. Reclaiming the Chinese revolution. Journal of Asian Studies 67(4):

1147-1164.

\section{Published Version}

doi:10.1017/S0021911808001733

\section{Permanent link}

http://nrs.harvard.edu/urn-3:HUL.InstRepos:10885502

\section{Terms of Use}

This article was downloaded from Harvard University's DASH repository, and is made available under the terms and conditions applicable to Open Access Policy Articles, as set forth at http:// nrs.harvard.edu/urn-3:HUL.InstRepos:dash.current.terms-of-use\#OAP

\section{Share Your Story}

The Harvard community has made this article openly available.

Please share how this access benefits you. Submit a story.

Accessibility 


\title{
Reclaiming the Chinese Revolution
}

\author{
Elizabeth J. Perry
}

\begin{abstract}
Focusing on the Chinese Communists' mobilizational efforts at the Anyuan coal mine in the early 1920s, the author argues for reconsidering a sometimes forgotten part of Chinese revolutionary history. At Anyuan, idealistic young Communist cadres led a highly successful non-violent strike and launched a major educational program for workers, peasants and their families. The result was a remarkable outpouring of popular support for the Communist revolutionary effort. Although the meaning of the "Anyuan revolutionary tradition" has been obscured and distorted over the years to serve a variety of personal, political and pecuniary agendas, the author seeks to recover from its early history the possibility of alternative revolutionary paths, driven less by class struggle and cults of personality than by the quest for human dignity through grassroots organization.
\end{abstract}

Elizabeth J. Perry (eperry@gov.harvard.edu) is Director of the Harvard-Yenching Institute and Henry Rosovsky Professor of Government at Harvard University.

\section{Revolutionary Reversals}

Revolutions are unpopular these days, among Western politicians and scholars alike. We put our faith in liberal institutions such as markets and courts of law, looking to "democratic transitions" rather than to social revolutions as the path toward political progress. The view of revolution as a nasty and needless mistake was evident twenty years ago when celebrations surrounding the bicentennial of the French Revolution evoked debate and discomfort both inside and outside of France. Then British Prime Minister Margaret Thatcher, after leaving Paris on Bastille Day of 1989, tapped into the 
prevailing sentiment when she presented President Mitterand with a handsome edition of Charles Dickens' A Tale of Two Cities, and smugly instructed the French President to read Dickens to learn why the French Revolution had been completely unnecessary (Reedy 1992).

The assessment of social revolution as a tragic misadventure is not confined to conservative politicians. It can be found in influential scholarly accounts from Francois Furet's Revolutionary France to Simon Schama's Citizens and Arno Mayer's The Furies, which expose the French and Russian Revolutions as replete with gratuitous violence and suffering (Furet 1992; Schama 2004; Mayer 2000). Among scholars of the Chinese revolution, we encounter a similarly grim conclusion. Roderick MacFarquhar and Michael Schoenhals, in their Mao's Last Revolution, describe China's Cultural Revolution as "an ever-widening campaign of terror during which ... people were tortured, maimed, driven mad, killed or committed suicide" $(2006,252)$. To explain this deplorable behavior, they point to Mao's revolutionary past: "Perhaps he was vicariously reliving his glory days of mobilizing peasants in Hunan and Jiangxi” $(2006,102)$. My own book, Patrolling the Revolution, highlights recurring terrorist tendencies that marred the Chinese revolutionary project from the 1920s through the Cultural Revolution (Perry 2005).

These days we recoil from the senseless violence of the revolutionary past, and place our hopes for the future in liberal democratic reform. But this repudiation of revolution is a fairly recent phenomenon. For most of the past two centuries, social revolutions - and the Chinese revolution in particular - were generally viewed by Western observers in a more positive light. ${ }^{1}$ 
In 1853, Karl Marx, upon learning of the Taiping Uprising in China, waxed euphoric; he wrote, "it may safely be augured that the Chinese revolution will throw the spark into the overloaded mine of the present industrial system and cause the explosion of the long-prepared general crisis which, spreading abroad, will be closely followed by political revolutions on the Continent” (Marx 1951, 7). Clearly Marx didn’t know much about the bizarre beliefs and practices of the millenarian Taipings - whose leader was claiming to be the younger brother of Jesus Christ - yet Marx looked to revolution in China as a trigger for worldwide political progress.

A century later the economist William Lockwood, referring to the above prediction, observed in his presidential address to this Association that "Marx may yet be right about China - in the twentieth century if not the nineteenth" (Lockwood 1964, 346). At the time of Lockwood's address in 1964, the Chinese revolution was led by a selfdeclared Communist rather than a self-styled Christian, but it was still regarded as capable of igniting global transformation. Mao's Cultural Revolution, which would erupt only two years after Lockwood delivered his remarks, prompted a whole new generation of Asianists in the West to look to the Chinese revolution as a source of political inspiration.

Indeed, I imagine it is fair to say that many members of our Association were initially drawn to the Asian field because we once held a favorable view of the Chinese revolution. Forty years ago, in the spring of 1968, the Association for Asian Studies convened its annual meeting in Philadelphia. That occasion was marked by a subgathering of Asianists who opposed the War in Vietnam, out of which was born the Committee of Concerned Asian Scholars (CCAS). ${ }^{2}$ The many budding young Asianists 
who soon joined CCAS, myself included, were generally united in a conviction that the War in Vietnam represented an epochal clash between a dynamic Asian revolutionary upsurge, stirred by the example of Mao's China, on the one hand; and a destructive American imperialism, bolstered by the work of some prominent members of the Asian studies establishment, on the other. ${ }^{3}$

But that was then. These days the Chinese revolution attracts few admirers in the American academy, among either younger or older generations. Indeed, some who argued most forcefully for the positive contributions of the Chinese revolution back then are among its harshest critics today. Joseph Esherick, author in 1972 of a provocative essay in defense of Mao's revolution entitled "Harvard on China: the Apologetics of Imperialism," twenty years later offered a sober reassessment. (Esherick 1972, 9-17; Esherick 1995). In his 1995 reappraisal, Esherick writes that "the narrative of revolutionary progress (and of progress through revolution) is no longer compelling" $(1995,39)$. The Chinese revolution, he asserts "was not a Liberation, but (for most) was the replacement of one form of domination with another" $(1995,41)$. Similarly, Mark Selden who in his 1971 book, The Yenan Way in Revolutionary China, had written that "The Chinese revolution ... offers inspiration ... to ... men and women everywhere who seek to create a society free from stifling oppression [and] arbitrary state power"(viiviii), ${ }^{4}$ by 2005 in his co-authored book with Edward Friedman and Paul Pickowicz pictures Mao's revolution as having alienated Chinese society from an increasingly oppressive authoritarian state. They write "The more revolution advanced, the more ... the state seemed parasitic ... Revolutionary dynamics splintered society from the state, 'us' from 'them'” (Friedman, Pickowicz and Selden 2005, 123). 
I mention these reversals not to embarrass my good friends by dredging up ancient arguments that they have long since disavowed. After all, at the outset of the Cultural Revolution, few among us appreciated the extent to which Mao's machinations were generating such extreme manifestations of oppression and alienation. Rather I draw attention to their earlier statements because I want to suggest, unpopular though such a suggestion is today, that there may be something worth retrieving from our youthful idealism about the Chinese revolution.

My purpose is certainly not to discount or downplay the brutality of China's revolution - whether perpetrated by Hunan peasant associations in 1927 or by Beijing Red Guards forty years later. It is entirely appropriate that as scholars we should reveal and repudiate such atrocities. But violence and bloodshed were only part of the Chinese revolutionary tradition. There was, I would like to suggest, another more positive side that also deserves to be recovered and perhaps even reclaimed.

In proposing that the Chinese revolution be reclaimed, I am not alone. The President of China, Hu Jintao, speaks often of "carrying on the revolutionary tradition"without, however, clarifying what that tradition actually means. As he put it, with characteristic vagueness, in a speech delivered at the site of the former Jiangxi Soviet, "Comrade Mao Zedong and other revolutionaries of the elder generation ... bequeathed to us precious spiritual wealth." 5 The failure to specify what this "spiritual wealth" involves has not prevented the Chinese government from trying to convert it into a more tangible form of wealth. Under the officially sponsored "red tourism" program, launched by the Chinese government a few years ago, travel to the sacred sites of Mao's revolution is being vigorously encouraged as a vehicle both for promoting state legitimacy and for 
pumping revenues into what remain some of the poorest regions of the Chinese countryside (Kirk 2008).

\section{The Anyuan Revolutionary Tradition}

Considering the actual outcome of Mao's revolution, it is easy to be cynical about the Chinese government's current effort to re-package and re-sell it to a new generation. Yet along the increasingly commercialized "red tourism" route designated by the National Tourism Administration is a place - Anyuan - whose history points, I believe, toward a more inspiring interpretation of the Chinese revolution. ${ }^{6}$ Located amidst the scenic Wugong Mountains of western Jiangxi Province (across the border from Mao Zedong's boyhood home in Hunan Province), Anyuan is the site of a large coal mine where a hugely successful non-violent strike occurred in the fall of 1922. Anyuan's socalled "great strike," in which its entire workforce of over 13,000 miners and over 1,000 railway workers walked off the job in unison, became a milestone in the annals of the Chinese revolution. Because the strike was directed by some of the most famous leaders of the Chinese Communist Party, it has drawn the attention of historians, novelists, painters, poets, playwrights and film-makers alike. ${ }^{7}$

Most of the very considerable attention that the history of Anyuan has attracted within China revolves around the politically sensitive question of which of three prominent young Communist leaders who were active at the coal mine in the early $1920 \mathrm{~s}$ - Li Lisan, Liu Shaoqi and Mao Zedong - deserves how much credit for the rather extraordinary things that transpired there. Statues of these three individuals, which were recently erected at Anyuan, reflect the current official party verdict on their relative contributions: a towering, full-sized statue for Mao; a more modest, a three-quarters-sized 
statue for Liu; and a mere half-sized statue for Li. These proportions are the exact inverse of own evaluation of their respective contributions to the Anyuan revolutionary tradition. But much more important than the relative standing of these three individuals is that the ordinary workers of Anyuan are often lost in the debate. ${ }^{8}$

It was Anyuan's large concentration of workers that attracted the interest of the young Mao Zedong immediately after the founding of the Chinese Communist Party. Charged by the party with overall responsibility for organizing workers in the greater Hunan region, Mao fixed his sights upon Anyuan as a promising base for proletarian revolution. When Mao visited the coal mine for the first time in the fall of 1921, he discovered in his conversations with the illiterate workers there that they were enthusiastic about the prospect of free education. Mao Zedong (who was then working as a teacher in Changsha) thereupon dispatched 22-year-old Li Lisan, fresh from his studies in France, to open a school for workers at Anyuan. Thanks to a friend of his father's who directed the Anyuan Chamber of Commerce, Li Lisan was able to gain official approval from the county magistrate for his pedagogical project. Li Lisan's school (which offered night classes for workers and day classes for their children) would serve as the springboard for a labor union, a workers' consumer cooperative and then - when the mining company threatened to shut down these grassroots organizations -- a strike.

Before giving the green light for the strike, Mao explicitly directed Li Lisan and his other Communist lieutenants at Anyuan not to present their protest in terms of Marxist class struggle. Borrowing a phrase from the legendary Daoist philosopher, Laozi, Mao called for an appeal to public sympathy with a non-violent uprising framed as a plea for human dignity. Following Mao's advice, Li Lisan came up with a stirring slogan for 
the Anyuan strike that would serve as the watchword of the Chinese Communist labor movement: "Once beasts of burden; now we will be human" (congqian shi niuma; xianzai yao zuo ren) (Yang 2003, chapter 2).

Maintaining discipline among the unruly coal miners, most of whom were members of the Triad secret society and were well accustomed to violence, was no easy feat. Mao was sufficiently worried about the potential for bloodshed that a few days before the strike was launched, he sent to Anyuan 24-year-old Liu Shaoqi, just back from training in the Soviet Union, specifically for the purpose of restraining the workers and preventing mass violence. Aware of the hold that the Triads exercised over the work force, Liu urged Li Lisan to pay a personal visit to the Triad chieftain in order to win his support for the strike. When the secret society chieftain agreed to shut down all the gambling and opium dens in the area and to prevent looting for the duration of the work stoppage, the Communists were ready to proceed. After a five-day strike, with no loss of life, no injuries and no serious property damage, the workers won a major victory (negotiated by Li Lisan and Liu Shaoqi) that brought higher wages, better working conditions, and a guarantee of security and financial backing for their labor union. For the next three years, while the Communist labor movement met with brutal suppression across most of China, Anyuan stood out as a notable exception (Liu Shaoqi yu Anyuan, 1981).

Thanks to the widespread public support that the non-violent strike generated, Anyuan flourished as a center of revolutionary activism in the years that followed. Known in progressive circles as China's "Little Moscow," Anyuan was home to over one-fifth of all the Communist Party members in the country by the spring of 1924 (Yang 
$2003,129)$. The great majority of these party members were formerly illiterate coal miners who - after receiving education at the night schools established and operated by the Communists -severed their Triad ties to join first the union and then the party. The Anyuan labor union, or workers' club (gongren julebu) as it was known, was splendidly rebuilt under Liu Shaoqi's direction in what he claimed was the style of the Bolshoi Grand Theater in Moscow. In addition to providing social welfare, the Anyuan workers' club operated a full and lively program of lectures, debates, dramas, films, art exhibits, and other politically inspired cultural and educational activities (Yang 2003, 132-1332; Zhang 1995, 167).

Thanks to substantial funding from the mining company, together with monthly dues deducted from members' wages, the Anyuan union was able to sponsor a major program of basic education designed for workers and their families. By 1924, more than $60 \%$ of the budget of the Anyuan workers' club went to support this pedagogical effort. Seven schools and dozens of literacy classes and reading rooms, staffed by young Communist teachers and directed at peasants as well as workers, were opened across western Jiangxi and eastern Hunan (Anyuan lukuang gongren yundong 1990, vol. 1: 334359). The first party school for cadre training was also established in Anyuan, further gilding its reputation as China's "Little Moscow" (Li Jianjun 2002, 219-226).

Although the Anyuan experiment was eventually crushed by warlord and Nationalist armies, its educational initiative left a lasting impression on the workers whose lives had been transformed by it. In the more than 2,000 Anyuan workers' memoirs later collected by party historians and stored today in the archives of the Anyuan Labor Museum, one theme predominates - namely the newfound sense of dignity and 
respect that the once downtrodden miners enjoyed as denizens of Little Moscow. Many of these workers' memoirs recall that, although the miners were belittled as beasts of burden before the strike, after the strike the workers of Anyuan were routinely addressed by members of the local elite with the exalted salutation of wansui $(10,000$ years - banzai in Japanese - a call for immortality that had once been reserved for emperors) (Hongse Anyuan 1959, 149-150; Zhang 1995, 137-138; Liu Shaoqi zai Anyuan 1980, 38-40.)

Anyuan was the training ground for many of China's most influential revolutionary pioneers and the source of thousands of worker-recruits who later became the backbone of the Autumn Harvest Uprising and the Communist Red Army (Wang Yang 1993). Because the history of Anyuan was closely connected to the later development of the Chinese revolution, it is not surprising that future generations would vie for the right to claim Anyuan's "revolutionary tradition" as their own. In the process, however, the legacy of Anyuan has been interpreted, reinterpreted, stretched and distorted to suit a wide array of competing agendas.

\section{Reframing the Anyuan Revolutionary Tradition}

The famous oil painting entitled Chairman Mao Goes to Anyuan [Figure \#1 “Chairman Mao Goes to Anyuan”- 1967 oil painting by Liu Chunhua] epitomizes the efforts of later generations to rework the Anyuan story for their own purposes. ${ }^{9}$ Completed in 1967 by a 22-year-old art student named Liu Chunhua, with help from his Red Guard cohort, the painting presents an idealized image of Mao Zedong, arriving at Anyuan in the fall of 1921 to organize among the miners and railway workers. It offers a romantic portrait of then 27-year-old Mao as a young intellectual, dressed in a scholar's gown and armed only with a Hunan umbrella, scaling the Wugong Mountains to embark 
on his revolutionary mission. In interviews with art historians many years later, Liu Chunhua indicated that the inspiration for his painting - the first oil painting he had ever completed - came in part from the religious paintings of Raphael (Andrews 1994, 338339). So sublime was Liu's image of Mao that a copy of the painting by an Indian artist reportedly hung in the halls of the Vatican for several months in 1969 under the title, "Young Chinese Missionary," until someone discovered its true provenance and had it hastily removed (Han 1972, 95).

Liu's oil painting was promoted during the Cultural Revolution by Mao's wife as a "revolutionary masterpiece" on a par with her eight model operas. ${ }^{10}$ It was the central work in a special exhibition at China's Museum of the Revolution in the summer of 1967, entitled “The Brilliance of Chairman Mao's Thought Illuminates the Anyuan Labor Movement." The exhibition was part of the brutal campaign to discredit Mao's then nemesis, Liu Shaoqi, by claiming that Mao - rather than Liu (let alone Li Lisan who had been attacked 15 years before) - deserved sole credit for the famous Anyuan strike of 1922. An earlier painting of Liu Shaoqi at Anyuan by Hou Yimin was now repudiated as a "poisonous weed" for depicting Liu, rather than Mao, as the hero of Anyuan (Laing, 1988, 68). Liu Shaoqi (who, along with Li Lisan, died under tragic circumstances in the Cultural Revolution) was roundly denounced as a rightist for having advocated a nonviolent strike that allegedly prevented workers from expressing their true revolutionary spirit. ${ }^{11}$

On the anniversary of the founding of the Chinese Communist Party, in July 1968, the major newspapers and magazines filled their front pages with color photos of the painting of Mao at Anyuan. The cult of Mao -who was now heralded as the sole 
protagonist of the Chinese revolution - was in full gear. Soon reproductions of the painting cropped up everywhere: from Mao buttons and postage stamps to embroidery and pottery renditions. This is said to be the most reproduced work of art ever - with over 900 million poster copies in circulation at one time. The painting was used in the campaign to send tens of millions of young people up to mountains and down to the countryside, as former Red Guards were urged to follow Chairman Mao's example in devoting their own lives to the cause of the revolution (Andrews 1994, 338-342 ; Laing 1988, 67-70).

In 1969 Liu Chunhua's oil painting was designated as a "national treasure" to be kept at the Museum of the Revolution as part of its permanent collection. After the Cultural Revolution, however, the no-longer-so-young artist regained possession of his youthful creation. In 1995 he sold the painting at a public auction to the Guangzhou branch of the Chinese Bank of Construction for 5.5 million yuan. But China is now officially a nation governed by courts of law as well as by markets, and in 1998 the Museum of the Revolution sued Liu Chunhua in the Beijing Intermediate Court, claiming that the painting was state property and should be returned to the museum. At the same time, other members of Liu's former Red Guard cohort - insisting that the painting was a collective work of revolutionary art -- sued Liu for what they alleged was their fair share of the auction price. Four years later, the court ruled that although Liu Chunhua alone held the copyright to the painting, and thus could retain the proceeds from his sale, the right of ownership actually rested with the state. Liu was rebuked for having sold a painting that he did not technically own, but due to a statute of limitations the court ruled that the Museum of the Revolution could no longer legally reclaim its rightful 
possession. ${ }^{12}$ And thus the matter rests. Youthful revolutionary zeal had long since been displaced by other calculations.

The tortuous history of Liu Chunhua's painting can be read as a metaphor for the fate of the Chinese revolution. Created by idealistic young intellectuals yearning to advance the cause of progressive social and political change, not so unlike many of us forty years ago, this romantic image became a vehicle for the state-orchestrated deification of a tyrannical despot, the crushing of his enemies in a vicious reign of terror, the disillusionment of millions of young people, and eventually the devolution of China's revolutionary tradition into a commercialized caricature of its original aims.

\section{Alternative Historical Possibilities}

So what is left to "reclaim" from the Chinese revolutionary experience? Current scholarship has largely abandoned Marx's faith in revolutionary class struggle as the locomotive of world history. But does our less deterministic understanding of history mean that we can now reject the necessity of revolution altogether? I am reminded of the answer that Benjamin Schwartz, another former president of this Association, gave shortly before his death in 1999 to the question of whether or not the Chinese Revolution had been necessary. Professor Schwartz replied that although "the” Chinese Revolution surely had not been necessary, “ $a$ ” Chinese Revolution probably had been necessary. ${ }^{13}$ China may not have needed the revolution it actually got -with all the brutality it entailed - yet China probably did need some sort of mass awakening and uprising to break the grinding poverty and inequality that gripped its pre-revolutionary society. Schwartz's characteristically nuanced response invites us to consider multiple historical legacies and 
possibilities - to focus not only on what went wrong with the Chinese revolution, but also to recognize what went right and to imagine what might have gone better.

To envision alternative trajectories for the Chinese revolution requires that we handle with caution the voguish social science concept of "path dependence," in which a pattern of interaction - once chosen - is said to lead to more and more of the same, even when a different pattern might have been more efficient or beneficial. ${ }^{14}$ While path dependent analysis has had the salutary effect of encouraging social scientists to undertake historical research in order to explain the origins of contemporary institutions and practices, it has had the unfortunate side-effect of severely limiting our historical imagination. The road from the Bastille to the Guillotine, or from the Red Terror of the Hunan and Jiangxi peasant associations in 1927 to the Red Terror of the Beijing and Shanghai Red Guards in 1967, becomes all too direct and predictable. In seeing the violence of the Cultural Revolution as the path dependent culmination of earlier patterns, we run the risk of over-determining and over-simplifying the lessons to be learned from Chinese revolutionary history, full as it is of contradictions and reversals, humanity as well as horror. ${ }^{15}$

The brutality of China's rural revolution is often equated with the Hunan peasant associations, whose violence was so famously praised in Mao Zedong's 1927 Report on an Investigation of the Hunan Peasant Movement. As it happens, these peasant associations were largely founded and directed by former Anyuan workers who had attended Li Lisan's night school, participated in the strike of 1922, and then joined the Communist Party during the years when Anyuan served as the heart of the Chinese labor movement. When the Communist movement at Anyuan was crushed by warlord troops 
in the fall of 1925, thousands of coal miners were forcibly repatriated to their native villages in Hunan and Jiangxi. They then set about organizing the peasant associations of which Mao Zedong would write so passionately two years later (Yu 2001, 142-170).

The Hunan and Jiangxi peasant associations, like the Anyuan labor movement of which they were a direct offshoot, began as an initiative to promote education and economic cooperation among the poor. But the Northern Expedition's ruthless military campaign to eliminate the warlords soon changed the dynamic. Chiang Kai-shek, as commander of the Northern Expedition, visited the Anyuan coal mine in September 1926 and called upon the workers to attack the capitalists and seize direct control of the mine a more radical proposal than the Communists had ever made. ${ }^{16}$ A few days later, Chiang personally approved the execution of the general foreman of the Anyuan coal mine - at the hands of former miners who were now soldiers in his National Revolutionary Army (Yang 2003, 199-200). The Northern Expedition spread in its wake what Hans van de Ven has characterized as "nasty cultures of violence" $(2003,95)$. In the process, the peasant associations turned into the terrorist tribunals that caught Mao Zedong's eye in early 1927, prompting him to write what are perhaps his most memorable and most frequently quoted lines:

A revolution is not a dinner party, or writing an essay, or painting a picture, or doing embroidery; it cannot be so refined, so leisurely and gentle, so temperate, kind, courteous, restrained and magnanimous. .... The rural areas need a revolutionary upsurge, for it alone can rouse the people in their millions to become a powerful force. . . (Mao 1971, 30).

Mao's praise for the Red Terror notwithstanding, recently released internal party documents from that time reveal that the Central Committee of the Chinese Communist Party issued a string of directives in 1927 ordering its organizations at all levels to put an 
immediate halt to the violence (Zhang 2000, 702). And even Mao's own enthusiasm for the excesses of the peasant associations was short-lived. Stephen Averill in his posthumously published book, Revolution in the Highlands, points out that by January 1928 Mao was already questioning the wisdom and effectiveness of the Red Terror in favor of returning to a more moderate approach aimed at preserving the rural economy (2006, 234-237).

Thus rather than draw a straight line from 1927 to 1967, and view the entire revolution as an unremitting scene of path-dependent violence, I would urge us to reconsider the many other highways, byways, shortcuts and detours that Mao and millions of his fellow revolutionaries traveled both before and after these bloody upsurges. To be sure, student Red Guards who placed dunce caps on their victims in the Cultural Revolution and paraded them through the streets of Beijing and Shanghai were imitating behavior that Mao had described in his 1927 Hunan report. ${ }^{17}$ But such connections do not establish any predictable or preordained route that the Chinese Revolution was destined to travel. Nor do they exhaust the patterns to be found in the Chinese revolutionary record. The Anyuan experiment - which provided education, organization and dignity to tens of thousands of workers, peasants and their families -suggests another revolutionary tradition worth recognizing.

Needless to say, 1920s Anyuan was no paradise. In this rough coal mining town, even in the heyday of Little Moscow, conflicts erupted frequently among the workers, and on occasion between workers and their Communist leaders. ${ }^{18}$ Yet despite very real difficulties, it seems clear from numerous first hand accounts that life in Anyuan prior to the Northern Expedition was experienced by thousands of downtrodden coal miners as a 
genuine Liberation. Although its meaning has been obscured over the years by political posturing and cults of personality, Anyuan's revolutionary tradition represents an effort driven less by violent class struggle than by the quest for human dignity.

Today, appalled by later events, we are hard pressed to look charitably upon any part of Chinese revolutionary history. It is easy to see why a book like Jung Chang and Jon Halliday's Mao: The Unknown Story, which depicts the revolution as a cynical and sadistic enterprise from start to finish, would strike a chord among contemporary readers (Chang and Halliday 2005). In light of the current climate, a favorable account of the Chinese revolutionary experience appears naïve and even apologetic. But eye-witness observers at the time, representing a wide range of ideological persuasions, uniformly credited the Communist experiment at Anyuan with impressive achievements, especially in the realm of mass education and organization.

Let us consider three such accounts, reflecting a spectrum of political perspectives. First, that of the American journalist Nym Wales, who interviewed many former Anyuan workers in Yan'an and who wrote in her general history of the Chinese labor movement the following:

The most active center was ... An-yuang [Anyuan] ... where 20,000 miners had won a big strike in 1922. Here the organization of the workers was very strong. Schools were founded, even for the miners' children, and educational work at the mines was carried on all during the 1923-1925 period (Wales 1945, 40).

Nym Wales, like her husband Edgar Snow, was of course sympathetic to the Communist revolution. So consider next the account of a less friendly source -- an American missionary who visited Anyuan in 1925 to inspect the activities of the large Episcopal church located there. The St. James Episcopal church, which boasted a congregation of 
several thousand Anyuan residents, was in direct competition with the Communist workers' club, for converts to fill its pews as well as for students to enroll in its parish schools. Yet the Reverend Walworth Tyng expressed grudging respect for the Communists' achievements. He wrote of his visit to the Anyuan workers' club the following:

All the men here belong to the Workingmen's Club, with a membership of thirteen thousand, led by young agitators with greater zeal than wisdom. As one enters the club building there faces one a giant portrait of Karl Marx ... There is a hall to hold 2,000 men, where exhortations are heard against capitalism. We find that men who feel too poor to pay their church pledges have their wages automatically deducted for Club dues regularly, and the Club is a force to be reckoned with - in some respects for good. Much of the Club income goes into maintaining schools (Tyng 1925, 477).

Finally, let us look at an account from an even more hostile source. The most telling testimony to the Communists' success at Anyuan can be found in the archives of their bitterest enemies. In September 1928, at the height of the Nationalists' White Terror against the Communists, the Nationalist military command prepared a top-secret memorandum on the progress of its rural pacification campaign in Central China. Noting that its mop-up effort was encountering exceptionally stiff resistance at Anyuan, the Nationalist military offered the following confidential explanation:

The reason the Communist Party has such a deeply rooted and firm foundation at Anyuan is because in the past the Communists carried out comprehensive "red education" at Anyuan. Six or seven years ago the Anyuan workers were all country bumpkins ... Not one of them could stand up at a meeting and say a word, let alone deliver a speech. Still less had any of them ever heard of organizing anything. It was only after the Communist bandit Li Lisan went to Anyuan ... that the knowledge of how to organize became widespread. Now workers were speaking up at public meetings and even giving lectures!

The Communists at Anyuan greatly valued education but they did not mechanically evangelize Communism like a missionary cramming a 
religious belief into a worker's head. At first they focused on literacy and basic knowledge. Every week they convened lectures as well as workers' debate societies and study groups....

Now all the important elements in the peasant associations in all the counties of Hunan are workers from Anyuan. . . . Today when one speaks with an Anyuan worker, everything he says is crystal clear. No longer is he a country bumpkin (Hunan qingxian gongbao). ${ }^{19}$

The Nationalists' White Terror ensured that Anyuan would never return to its former glory days as Little Moscow. But the Anyuan workers who had been awakened through education would also never revert to being "country bumpkins." Although their revolution - like the painting "Chairman Mao Goes to Anyuan" - would be hijacked by other personal, political and pecuniary agendas, its meaning and future directions could be re-imagined and reclaimed by later generations.

Today, among those laying claim to the Anyuan tradition are not only government officials and red tourists, but also avant garde artists who have recently redrawn the familiar image of "Chairman Mao Goes to Anyuan" in a variety of arresting and amusing ways. ${ }^{20}$ In 1991, for example, Liu Dahong elaborated upon the religious flavor of Liu Chunhua's original painting in a revisionist rendition entitled "Spring." Liu Dahong's work depicts the young Mao -with a halo over his head and red sun rising behind his back — delivering a Buddhist equivalent of the "Sermon on the Mount" atop the Wugong Mountains. In Liu Dahong's fanciful version, Mao - still dressed in his scholar's gown - has laid down his Hunan umbrella and wields in its place a magical beam of light. Other painters have eschewed religious iconography in favor of a more "modernized" image of Mao at Anyuan. Wang Xingwei's 1995 "The Way to the East" shows a contemporary Mao - dressed in an Armani suit and carrying a new Western umbrella in place of his old Hunan one - striding across the Wugong Mountains with his back turned 
away from Anyuan. Even foreign artists have gotten in on the fun. Erro Gudmundur's 2003 “Mao's Last Visit to Venice" positions Mao (still wearing his scholar's gown and clutching his Hunan umbrella) against an Italian cityscape. Others have injected a note of irony by adding or subtracting figures from the original rendition. Yin Zhaoyang's 2005 painting, entitled "Chairman Mao Goes to Anyuan," adds to the familiar scene atop the Wugong Mountains a worker waving at Mao- whether to attract the Chairman's attention or to bid him a final farewell remains ambiguous. In Yue Minjun's 2005 painting, also entitled "Chairman Mao Goes to Anyuan," we see a crystal clear Wugong landscape exactly replicating that of Liu Chunhua's original painting. But absent from Yue's work is any trace of Chairman Mao himself! $!^{21}$

\section{Conclusion}

Contemporary reinterpretations of the Chinese revolution - whether expressed in speeches by Communist party leaders, in "red" theme parks created by the National Tourism Administration, or in paintings by avant garde artists - often overlook the most important protagonists of the revolution: the ordinary Chinese people. But Anyuan is still a working coal mine today, and workers there continue to ponder the revolutionary past.

In a recent interview, conducted by Yu Jianrong of the Chinese Academy of Social Sciences, an Anyuan miner offered the following observation on his revolutionary tradition: "I can say for sure that if some people came to Anyuan today to organize a night school like Mao Zedong and Li Lisan did at the time of the great Anyuan strike, they would definitely be viewed as counter-revolutionaries and thrown in prison" ( $\mathrm{Yu}$ 2006, 278). In another interview, a miner remarked ruefully, "Workers' wages are sinking ... Workers' rights are shrinking ... Workers' living conditions are stinking .... 
These days our Anyuan workers' slogan goes like this, 'in the past we were beasts of burden, and now we are still not human"” (Yu 2006, 298).

Four years ago, a protest that I happened to witness at the Anyuan coal mine issued this manifesto:

During the years of revolutionary struggle, [we] Anyuan workers suffered and sacrificed for the sake of the Chinese revolution... The enterprise has prospered and yet we have not enjoyed the fruits of reform ... If you ignore this manifesto ... we will organize a large-scale demonstration ... Of course a confrontation is not our first choice; our first choice is a peaceful livelihood (Laodong tiaojian).

Today, as in the pre-revolutionary era, China is again a nation of haves and have-nots (Lee and Selden). But these days few of us look to Marxist class struggle as the solution to these glaring and growing inequities. In the wake of Iran's Islamic revolution of 1979, East Europe's anti-Communist revolutions of 1989, and Central Asia's color revolutions at the beginning of the $21^{\text {st }}$ century, Marx's model of revolution is no longer hegemonic (Fairbanks 2007). ${ }^{22}$

The literary critic Walter Benjamin once observed, "For Marx, revolutions are the locomotive of world history. But perhaps things are different. Perhaps revolutions are the way that humanity, riding on this train, reaches for the emergency brake" (quoted in Gilly 2003). If, as some predict, a concluding chapter of the Chinese revolution remains to be written in the $21^{\text {st }}$ century, let us hope that it will not follow some supposed pathdependent track of bloodshed and violence but will draw inspiration instead from another, more uplifting side of the Chinese revolutionary tradition. Although scholars may not be as creative as avant garde artists, surely we too have a responsibility to put our imaginations to work to envision how history might have -and might yet--travel along a 
different set of rails. The Chinese people have paid too high a price, inspired by too

hopeful a vision, for their revolution not to be recovered and reclaimed.

\section{ACKNOWLEDGMENTS}

I owe an enormous debt of gratitude to Yu Jianrong, who introduced me to the study of Anyuan and who has accompanied me on four highly illuminating research trips there. His own outstanding scholarship on this and other topics in grassroots Chinese politics has been a major inspiration to me. I would also like to thank Yan Xiaojun, Lu Lei, Ma Xiaohe, and Matthew Sommer for their assistance in locating primary sources, and Nara Dillon for suggestions on an earlier draft. Of course none of these individuals bears responsibility for any remaining errors of fact or interpretation.

\section{LIST OF REFERENCES}

Andrews, Julia F. 1994. Painters and Politics in the People's Republic of China, 19491979. Berkeley: University of California Press.

Anyuan lukuang gongren yundong [Anyuan railway and mining workers' movement]. 1990. ed., Pingxiang Communist Party Committee. Beijing: Chinese Communist Party Historical Materials Press (2 volumes)

Averill, Stephen C. 2006. Revolution in the Highlands: China's Jinggangshan Base Area. Lanham, MD: Rowman and Littlefield.

Chang, Jung and Jan Halliday. 2005. Mao: The Unknown Story. London: Jonathan Cape.

Esherick, Joseph W. 1972. "Harvard on China: The Apologetics of Imperialism." Bulletin of Concerned Asian Scholars, 4(4): 9-17.

. 1995. "Ten Theses on the Chinese Revolution." Modern China. 21 (1): 44-76;

reprinted in Twentieth Century China: New Approaches, ed. Jeffrey N. Wasserstrom, 3965. (London: Routledge, 2003). Citations are from the reprint.

Fairbank, John King. 1982. Chinabound: A Fifty-year Memoir. New York: Harper and Row.

Fairbanks, Charles H. Jr. 2007. “Revolution Reconsidered.” Journal of Democracy 18 (1): 44-53. 
Friedman, Edward. 1977. "The Innovator." In Mao Tse-Tung in the Scales of History, ed. Dick Wilson, 300-320. New York: Cambridge University Press.

Friedman, Edward, Paul G. Pickowicz, and Mark Selden. 2005. Revolution, Resistance and Reform in Village China. New Haven, CT: Yale University Press.

Furet, Francois. 1992. Revolutionary France, 1770-1880. Oxford: Blackwell Press.

Gilly, Adolfo. 2003. "Globalization, Violence and Revolutions: Nine Theses.” In The Future of Revolutions. ed.,John Foran, 109. London: Zed Books.

Han, Suyin. 1972. The Morning Deluge: Mao Tsetung and the Chinese Revolution, 18531954. Boston: Little Brown.

Hongse Anyuan [Red Anyuan]. 1959. ed., Pingxiang Mining Company Propaganda Department. Nanchang: Jiangxi People's Press.

Hunan qingxiang gongbao (Bulletin on village pacification in Hunan). 1928. no. 11.

Kirk, Mollie. 2008. Patriotism for Sale: Communist Apologetics in the Red Tourism Program. Cambridge, MA: Harvard University Senior Honors Thesis, East Asian Studies.

Laing, Ellen Johnston. 1988. The Winking Owl : Art in the People's Republic of China. Berkeley: University of California Press, 1988.

Laodong tiaojian zui cha, gongzuo zui jianku, zui weixian, dui guojia he qiye gongxian zui da de pingkuang tuixiu zhigong tuixiu yanglaojin dixia [The dwindling pensions of retired Pingxiang miners whose labor conditions were the worst, whose work was the most difficult and dangerous, yet whose contribution to country and enterprise was the greatest]. Unpublished protest manifesto (Anyuan, Jiangxi: 2004).

Lee, Ching Kwan and Mark Selden, “China's Durable Inequality: Legacies of Revolution and Pitfalls of Reform," Japan Focus. This online electronic journal can be accessed at http://japanfocus.org/

Li Jianjun. 2002. "Zhonggong Anyuan diwei dangxiao shiliaokao" [Historical materials on the party school at Anyuan]. In Anyuan lukuang gongren yundongshi yanjiu huibian [Compilation of studies of the history of the Anyuan labor movement], eds., Wen Peiwu et.al., 219-226. Nanchang: Jiangxi People's Press.

Liu, Shanwen. 1993. Anyuan lukuang gongren yundong shi [History of the labor movement of Anyuan railway workers and miners]. Shanghai: Shanghai Academy of Social Sciences.

Liu, Shaoqi. 1988. Liu Shaoqi lun gongren yundong (Liu Shaoqi discusses the labor movement). Beijing: Central Documents Press. 
Liu Shaoqi yu Anyuan gongren yundong [Liu Shaoqi and the Anyuan labor movement]. 1981. ed., Anyuan Labor Museum. Beijing: Chinese Academy of Social Sciences Press. Lockwood, William W. 1964. "Adam Smith and Asia." The Journal of Asian Studies 23 (3): $345-355$.

Liu Shaoqi zai Anyuan de gushi [Stories of Liu Shaoqi at Anyuan]. 1980. Shanghai: Shanghai People's Press.

MacFarquhar, Roderick and Michael Schoenhals. 2006. Mao's Last Revolution. Cambridge, MA: Harvard University Press.

Mahoney, James and Dietrich Rueschemeyer, eds. 2003. Comparative Historical Analysis in the Social Sciences. Cambridge: Cambridge University Press.

Mao, Zedong. 1971. "Report of an Investigation of the Peasant Movement in Hunan." In Selected Readings from the Works of Mao Tsetung. Beijing: Foreign Languages Press.

Marx, Karl. 1951. Marx on China, 1853-60: Articles from the New York Daily Tribune. London: Lawrence and Wishart.

Mei, Fangquan. 2006. Anyuan kuanggong: zhuanxingqi de bianqian yanjiu [Anyuan miners: a study of change in transitional times]. Beijing: Chinese Academy of Social Sciences Press.

Mayer, Arno. 2000. The Furies: Violence and Terror in the French and Russian Revolutions. Princeton, NJ: Princeton University Press.

Moore, Barrington, Jr. 1966. Social Origins of Dictatorship and Democracy: Lord and Peasant in the Making of the Modern World. Boston: Beacon Press.

Perry, Elizabeth J. 2005. Patrolling the Revolution: Worker Militias, Citizenship and the Modern Chinese State. Lanham, MD: Rowman and Littlefield.

China 32(2). . 2007. "Red Literati: Communist Educators at Anyuan." Twentieth-Century

Paul Pierson. 2004. Politics in Time: History, Institutions and Social Analysis. Princeton, NJ: Princeton University Press.

Reedy, George E. 1992. "Sacred and Profane in Revolutionary France." The Review of Politics 54(1): 155.

Schama, Simon. 2004. Citizens: A Chronicle of the French Revolution. London: Folio Society. 
Selden, Mark. 1971. The Yenan Way in Revolutionary China. Cambridge, MA: Harvard University Press.

Smith, Karen. 2006. Nine Lives: The Birth of Avant Garde Art in New China. New York: Prestel.

Tyng, Walworth. 1925. "The Miners' Church at Peaceful Spring: Among the Collieries and Coke Ovens at Anyuen - A Vivid Picture of Our Work in a Little Known Part of the District of Hankow." The Spirit of Missions: 477.

van de Ven, Hans J. War and Nationalism in China, 1925-1945. New York: Routledge Courzon.

Wales, Nym. 1945. The Chinese Labor Movement. New York: John Day.

Wang Yang. 1993. Qiushou qiyi zai Jiangxi [The Autumn Harvest Uprising in Jiangxi] Beijing: Wenwu Press.

Yang, Furong. 2003. Zhonggong Pingxiang difangshi [Local history of the Chinese Communists in Pingxiang].Beijing: Chinese Communist Party History Press.

Yu, Jianrong. 2006. Zhongguo gongren jieji zhuangkuang: Anyuan shilu [The plight of China's working class: annals of Anyuan].Hong Kong: Mirror Books. . 2001. Yuecun zhengzhi [Hunan village politics]. Beijing: Commercial Press.

Zhang, Baohui. 2000. "Communal Cooperative Institutions and Peasant Revolutions in South China, 1926-1934." Theory and Society 29 (5).

Zhang, Zhenchu. 1995. Anyuan yishi [Anyuan anecdotes]. Pingxiang: Pingxiang Mining Company.

\footnotetext{
${ }^{1}$ Barrington Moore, Jr. wrote in 1966, "the costs of moderation have been at least as atrocious as those of revolution, perhaps a great deal more" $(1966,505)$.

${ }^{2}$ For one account of this tumultuous period in the history of Asian studies, see Fairbank (1982, 399-400).

${ }^{3}$ See the early issues of the Bulletin of Concerned Asian Scholars (launched in May 1969) for writings by some of the founding members of CCAS.
} 
${ }^{4}$ As late as 1977, Selden's future collaborator, Edward Friedman, wrote: "Mao by the example of his struggle communicates the vigour of hope, the vitality of possibility, the vision of justice. Mao's message to the $20^{\text {th }}$ century is elegantly simple: what should be can be" (Friedman 1977, 320).

${ }^{5}$ For a description of Hu Jintao's visit to the Jiangxi revolutionary base areas, see Renmin ribao [People's Daily] (September 3, 2003).

${ }^{6}$ I am currently writing a book-length study of the Anyuan revolutionary tradition. A preliminary publication on this topic is my 2007 article in Twentieth-Century China.

${ }^{7}$ Among the many accounts of the Anyuan strike and its aftermath, perhaps the most comprehensive and reliable is Liu Shanwen (1993).

${ }^{8}$ Two important exceptions, based upon recent ethnographic research, are $\mathrm{Yu}$ (2006) and Mei (2006).

9 The painting was reproduced on the program cover for the 2008 annual meeting of the Association for Asian Studies. Further details on the painting can be found in the program.

10 Mao himself, according to Zhang Chunqiao (a member of the so-called "Gang of Four"), expressed dissatisfaction with the painting both because it included no workers and because it portrayed Mao in a scholar's gown. Zhang's statement, made during a visit to Shaoshan in 1971, can be found in the Anyuan Labor Movement Archives.

${ }^{11}$ Among the countless Cultural Revolution denunciations of Liu Shaoqi's prior activities at Anyuan, see for example Da gongzei Liu Shaoqi shi gongren jieji de sidi [Big scab Liu Shaoqi is the mortal enemy of the working class]. 1968. Hong Kong: Sanlian Press.

${ }^{12}$ Accounts of the auction and attendant law suits can be found in Nanfang zhoumo [Southern Weekend] (July 27, 2006); People's Daily Online (December 4, 2006); and www.chinanews.com (October 22, 2007).

13 Author's conversation with Benjamin Schwartz, 1999.

${ }^{14}$ Among the more insightful discussions of path dependency, see Mahoney and Rueschemeyer 2003; and Pierson 2004, chapter 1). James Mahoney and Dietrich Rueschemeyer, eds., Comparative Historical Analysis in the Social Sciences (Cambridge: Cambridge University Press, 2003); Paul Pierson, Politics in Time: History, Institutions and Social Analysis (Princeton, NJ: Princeton University Press, 2004): Chapter 1. ${ }^{15}$ Jung Chang and Jan Halliday, in their popular biography of Mao Zedong, trace what they characterize as Mao's "love for bloodthirsty thuggery" back to his experiences as a revolutionary organizer in Hunan and Jiangxi in the 1920s $(2005,41)$.

${ }^{16}$ Chiang Kai-shek referred to this incident in his diary entry for September 20, 1926 contained in the Archives of the Hoover Institution, Stanford University. My appreciation to Matthew Sommer and Hsieh Mei-yu for their help in locating this entry. For a press account of Chiang's visit to Anyuan and its aftermath, see Anyuan lukuang gongren yundong 1990, vol. 2: 1358.

${ }^{17}$ As Mao had written approvingly in 1927, "At the slightest provocation [the peasants] make arrests, crown the arrested with tall paper hats, and parade them through the villages. . . Doing whatever they like and turning everything upside down, they have created a kind of terror in the countryside" $(1971,29)$. 
${ }^{18}$ Liu Shaoqi later recalled how he and Li Lisan had been driven to tears by angry workers who threatened to beat them up when they refused to approve a second strike. See (Liu 1988, 216).

${ }^{19}$ This once highly classified account is held in the Anyuan Labor Movement Archives.

${ }^{20}$ For a general treatment of avant garde art in China, see Smith 2006.

${ }^{21}$ Copies of these and other paintings connected to Anyuan are all available on the web and were shown during the presidential address.

${ }^{22}$ Charles H. Fairbanks, Jr., "Revolution Reconsidered," Journal of Democracy, vol. 18, no. 1 (January 2007): 44-53. 